\title{
ОЗНАКИ ВИНИКНЕННЯ КРИЗ В СИСТЕМІ ДЕРЖАВНОГО УПРАВЛІННЯ
}

\section{SIGNS OF CRISIS IN THE PUBLIC GOVERNANCE SYSTEM}

\author{
Мартінович Віктор Геннадійович \\ кандидат економічних наук, доцент, \\ Черкаський державний технологічний університет \\ ORCID: https://orcid.org/0000-0001-5210-3026 \\ Руденко Оксана Анатоліївна \\ кандидат економічних наук, доцент, \\ Черкаський державний технологічний університет \\ ORCID: https://orcid.org/0000-0002-0713-5405 \\ Martinovich Victor, Rudenko Oksana \\ Cherkasy State Technological University
}

\begin{abstract}
У статті розглядаються ознаки виникнення та шляхи подолання криз в системі державного управління України та її вплив на ефективність проведення адміністративних реформ. Зазначено, що класифрікацію типів систем державного управління країн можна провести за структурними, структурно-срункціональними, фрункціонально-культурними чинниками та адміністративною культурою, що нерідко призводять до появи кризового стану із середини системи управління. Досвід країн Європейського Союзу свідчить, незважаючи на те, що не існує однієї оптимальної уніфрікованої моделі організації державного управління, уникнення кризових процесів, посилити адміністративну спроможність можливо лише за умови консолідації всіх політичних сил. Аналіз цього досвіду є надзвичайно корисним для формування та реалізації шляхів подолання криз в системі державного управління.
\end{abstract}

Ключові слова: державне управління, криза, організаційна структура, структурні чинники, адміністративна рефрорма.

В статье рассматриваются признаки возникновения и пути преодоления кризисов в системе государственного управления Украины и ее влияние на эффективность проведения административных реформ. Отмечено, что классификацию типов систем государственного управления стран можно провести по структурным, структурно-срункциональными, фрункционально-культурными фракторами и административной культурой, нередко приводят к появлению кризисного состояния с середины системы управления. Опыт стран Европейского Союза показывает, несмотря на то, что не существует одной оптимальной унифицированной модели организации государственного управления, во избежание кризисных процессов, усилить административную способность возможно лишь при условии консолидации всех политических сил. Анализ этого опыта является чрезвычайно полезным для формирования и реализации путей преодоления кризисов в системе государственного управления.

Ключевые слова: государственное управление, кризис, организационная структура, структурные фракторы, административная ресорма.

The article considers the signs of emergence and ways to overcome crises in the system of public administration of Ukraine and its impact on the effectiveness of administrative reforms. It is noted that the classification of types of public administration systems can be carried out by structural, structural-functional, functional-cultural factors and administrative culture, which often lead to a crisis from the middle of the management system. The experience of the European Union shows that, despite the fact that there is no single unified model of public administration, avoidance of crisis processes, strengthen administrative capacity is possible only if all political forces are consolidated. The analysis of this experience is extremely useful for the formation and implementation of ways to overcome crises in the public administration system. The economic basis of the political crisis in Ukraine and its regions is oligarchic property, whose representatives control the system of public administration, local self-government and the political system of the country. Such a symbiosis in the face of opposition from domestic oligarchs has led to the lowest social development among the leading CIS countries. Ukraine's profitability is three times lower than in Russia and three 
times lower than in Belarus. The most likely scenario for overcoming the political crisis is to unite the oligarchic interests of the representatives of Ukraine and other states. In any case, the problem of low profitability of the country is not eliminated. To solve it, it is necessary to create a fundamentally new ownership structure as the economic basis for successful socio-economic development. Thus, the principles of effective anti-crisis public administration should be: scientific analysis and forecasting of trends; methodology for developing risky solutions; the quality of the anti-crisis program; strategy in management; the art of crisis management; professionalism of crisis management; efficiency, flexibility of management, time factor; crisis monitoring and human factor: staff, values, motivation.

Keywords: public administration, crisis, organizational structure, structural factors, administrative reform.

Постановка проблеми. Питання про місце і роль держави в організації економічного життя суспільства, у формах і методах регулювання економіки, можливість виникнення і подолання криз у державному управлінні економікою $€$ достатньо складними і дискусійними. У недавньому минулому багато політиків помилково вважали, що суспільно-економічна фрормація виключає можливість прояву криз.

В Україні ресрорма системи державного управління та організації $€$ основною стратегічною проблемою, що постала перед владою за часів незалежності і не вирішена й досі. Чинна система органів виконавчої влади та місцевого самоврядування не відповідає принципам демократії, європейським стандартам і відзначається надмірною централізацією, внутрішньою суперечливістю, особливо в умовах співпраці 3 Європейським Союзом. Вона стала перешкодою у проведенні соціально-економічних і політичних ресрорм, розвитку національної економіки України, нарощенню інвестиційно-інноваційного потенціалу.

Аналіз останніх досліджень і публікацій. Серед економістів, які внесли суттєвий вклад у дослідження за ознаками виникнення криз та напрямом їх подолання, слід відзначити іноземних вчених Е. Короткова [1], В. Баринова [2], А. Ряховську [3], М. Гапоненка [4]. Виявленню ознак кризи державного управління та шляхів ії̈ подолання присвячено наукові праці вітчизняних вчених В. Авер'янова, Н. Нижника [5], В. Лугового, В. Бакуменка, А. Чернявського, В. Беседіна, Т. Лебедєвої [6], І. Кривов'язюка [7], В. Дзюндзюка [8].

Виділення невирішених раніше частин загальної проблеми. Нині бракує комплексних досліджень, що визначають не лише передумови виникнення кризового стану соціально-економічної системи, але й їх взаємозв'язок 3 особливостями сучасних трансорормаційних процесів у суспільстві, 3 суперечностями його розвитку. Відчувається нестача наукових праць, присвячених об'єктивному визначенню масштабів роз- витку кризи, ії̈ характеристик в державному управлінні, напрямів розповсюдження.

Формулювання цілей статті. Наукове обґрунтування напрямів поліпшення економічного стану, ознак виникнення та шляхи подолання криз в системі державного управління.

Виклад основного матеріалу дослідження. Сьогодні немає людини, яку не хвилюють події, що відбуваються в Україні останнім часом. Їм присвячені виступи політиків, посадових осіб, публікації у пресі та наукових виданнях. В них акцентується увага на низькому рівні життя населення і розвитку регіонів, питаннях власності та управління економікою, національному питанні, зовнішніх інтересах окремих зарубіжних країн тощо.

Крім того, дослідники, що вивчали кризи, дійшли висновку, що видів цього явища дуже багато, їх можна систематизувати, класифрікувати за певними ознаками (табл. 1).

Здійснювати регулювання економікою можна саме через державне управління як спосіб реалізації державної влади, що означає:

1) право, можливість і спроможність держави через державні органи та посадових осіб здійснювати вплив на відносини й діяльність людей;

2) систему інститутів і державних органів, які мають повноваження приймати владні рішення;

3) діяльність окремих осіб, які володіють відповідними владними повноваженнями [6, с. 78].

Сутнісними ознаками державної влади та системи державного управління $€$ легітимність; офріційний характер; структурованість апарату влади; обов'язковий характер її рішень; можливість скасовувати постанови і рішення недержавних політичних організацій; наявність виключних прав і прав на примусове виконання рішень. На рис. 1 зображено основні функції держави, що забезпечують в цілому державний управлінських процес.

Державному управлінню притаманні певні форми і методи діяльності. Розрізняють декілька видів форм управлінської діяльності, 
Таблиця 1

Генезис поняття «кризи»

\begin{tabular}{|c|c|c|}
\hline $\begin{array}{l}\text { № } \\
\Pi / \Pi\end{array}$ & Автор & Поняття «криза» \\
\hline 1 & В.Д. Базилевич & $\begin{array}{l}\text { крайнє загострення протиріч у соціально-економічній системі, що } \\
\text { загрожує її життєстійкості в навколишнім середовищі }\end{array}$ \\
\hline 2 & Е. Коротков & $\begin{array}{l}\text { особливий переломний стан у розвитку і функціонуванні політичної } \\
\text { системи суспільства, державно-владних структур, що визначається } \\
\text { нестабільністю, розбалансованістю діяльності політичних інститутів, } \\
\text { зниженням рівня керованості соціально-економічними процесами, } \\
\text { загостренням політичних конорліктів, наростанням критичної } \\
\text { активності мас }\end{array}$ \\
\hline 3 & Е. Коротков & $\begin{array}{l}\text { об'єктивна риса та передумова розвитку будь-якої макро- та } \\
\text { мікроекономічної системи }\end{array}$ \\
\hline 4 & $\begin{array}{l}\text { С.Н. Козьменко, } \\
\text { А.Н. Андронов }\end{array}$ & $\begin{array}{l}\text { ситуативна характеристика фуункціонування будь-якого суб'єкта, що } \\
\text { є наслідком невизначеності в його зовнішньому та внутрішньому } \\
\text { середовищах }\end{array}$ \\
\hline 5 & Атаманчук Г.В & $\begin{array}{l}\text { загальна закономірність, зміна становища (різкий перехід від стабільності } \\
\text { до розбалансованості всього ланцюга відтворення) - результат } \\
\text { одночасної спільної негативної дії зовнішніх та внутрішніх фракторів }\end{array}$ \\
\hline 6 & Зуб А.Т. & $\begin{array}{l}\text { подія, яка здатна загрожувати життєдіяльності організації, } \\
\text { що характеризується невизначеними причинами і складно } \\
\text { передбачуваними наслідками та потребує прийняття нагальних рішень }\end{array}$ \\
\hline 7 & $\begin{array}{l}\text { Rosenthal and } \\
\text { B. Pijnenburg }\end{array}$ & $\begin{array}{l}\text { ситуація, позначена високою небезпекою, станом непевності, } \\
\text { відчуттям невідкладності, що притаманна ринковим відносинам }\end{array}$ \\
\hline
\end{tabular}

Джерело: розроблено авторами

унісрікованих за зовнішніми ознаками: встановлення і застосування норм права; організаційне регламентування внутрішньої роботи апарату органів влади; позаапаратна організаційна діяльність; матеріально-технічне забезпечення. Отже, основні ознаки кризи державного управління:

- загострення економічних і соціальних конфрліктів 3 яскраво вираженим політичним характером, оскільки вимоги адресуються структурам влади щодо зміни політичного курсу, стратегії та методів управління;

- нездатність державної влади керувати конорліктами, що поглиблюються, регулювати соціально-економічні процеси і відносини колишніми традиційними методами;

- розбалансованість структурно-фрункціональної системи управління і політичних інститутів влади, розрив конструктивних зв'язків з навколишнім середовищем;

- крах легітимності державної влади;

- напружений стан суспільства [10].

Структура механізму державного управління має такий вигляд (табл. 2)

Механізм державного управління може фрункціонувати за умови короткострокових криз, але системна криза державного управління, що веде до негативних наслідків i надалі, вимагає конкретних управлінських рішень. Системна криза державного управ- ління - це взаємна невідповідність економіки, соціальної сфрери, політики, права, тобто розбалансованість системи, яка не може бути подолана в рамках (без зміни) існуючого соціально-економічного ладу [2].

У цей доленосний для країни час необхідно практично реалізовувати пропозиції щодо виходу з кризи. Ці пропозиції повинні бути комплексними, зрозумілими не тільки для управлінської еліти, але і для народу.

В.М. Геєцем виділено низку загальних трансформаційних тенденцій в умовах змін, які $€$ основними складовими посткризового державного управління:

- перехід від його класичної консервативної моделі до креативної, такої, що оперативно реагує на зміни у світі та в суспільстві;

- необхідність приведення різноманітності державного управління у відповідність до різноманітності суспільства;

- підвищення його самоорганізаційної спроможності, тобто можливості забезпечення кращого варіанта управління в умовах, що склалися у суспільстві (сорері, галузі, певних відносинах);

- забезпечення збалансованого публічного управління та налагодження ефективного взаємозв'язку з населенням;

- підвищення й, частково, зміна ролі державної служби та служби в органах місцевого 


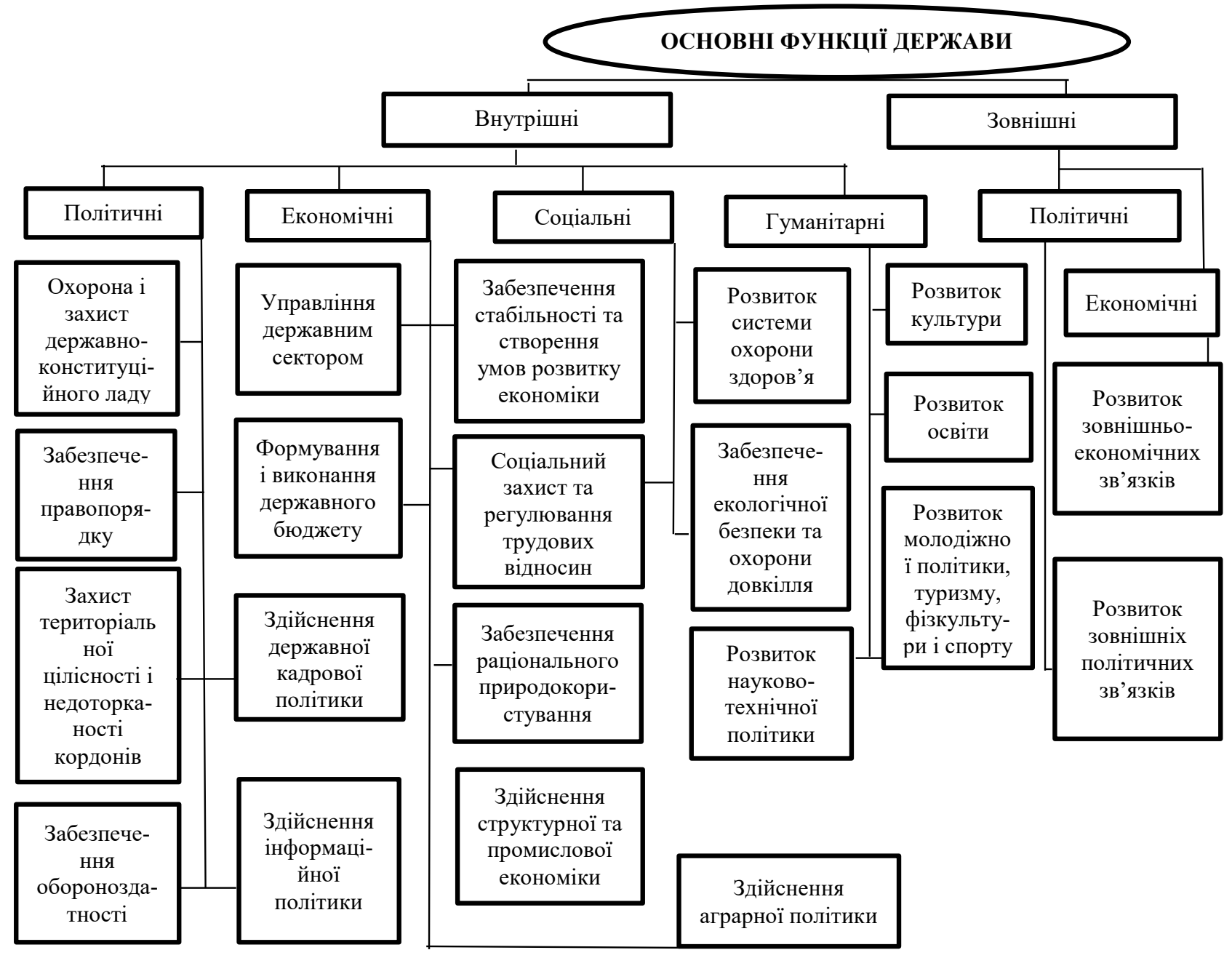

Рис. 1. Структура основних фрункцій держави Джерело: [5]

Таблиця 2

Узагальнена схема структури механізму державного управління

\begin{tabular}{|c|c|c|c|c|c|c|c|c|}
\hline \multirow[b]{2}{*}{$\begin{array}{l}\text { Елементи } \\
\text { механізму }\end{array}$} & \multicolumn{8}{|c|}{ Учасники відносин } \\
\hline & 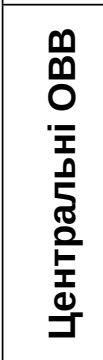 & 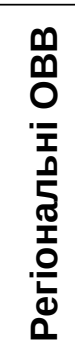 & 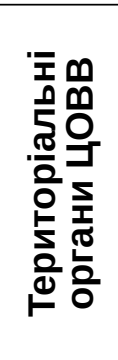 & 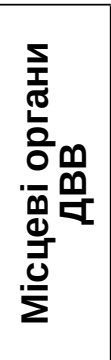 & 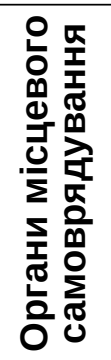 & 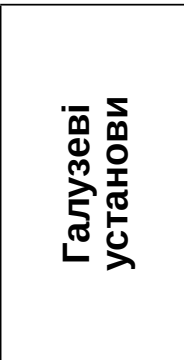 & 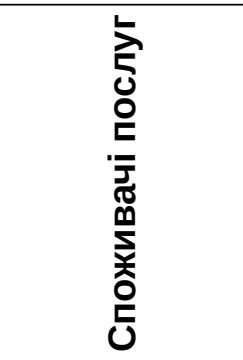 & 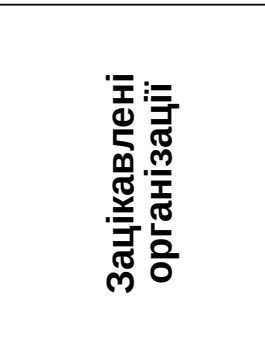 \\
\hline Цілі & \multicolumn{8}{|c|}{$\begin{array}{l}\text { Упорядкування та підвищення результативності економічної діяльності } \\
\text { суб'єктів ринку, забезпечення гідних умов життєдіяльності громадян України }\end{array}$} \\
\hline Принципи & \multicolumn{8}{|c|}{ Зафріксовані в установчих документах } \\
\hline Функції & \multicolumn{6}{|c|}{ Зафріксовані в установчих документах } & \multicolumn{2}{|c|}{ Фактичні } \\
\hline $\begin{array}{l}\text { Методи впливу } \\
\text { на процес }\end{array}$ & \multicolumn{5}{|c|}{$\begin{array}{l}\text { Правові, організаційні, економічні, } \\
\text { соціально-психологічні }\end{array}$} & \begin{tabular}{|c|} 
Надання \\
послуг
\end{tabular} & $\begin{array}{c}\text { Споживання } \\
\text { послуг }\end{array}$ & $\begin{array}{c}\text { Безпосередня } \\
\text { участь }\end{array}$ \\
\hline $\begin{array}{l}\text { Технології та } \\
\text { технічні засоби }\end{array}$ & \multicolumn{8}{|c|}{ Засоби зв'язку, комп'ютерна техніка тощо } \\
\hline Інфрормація & \multicolumn{8}{|c|}{ Висхідна, низхідна } \\
\hline
\end{tabular}


самоврядування як інформаційно-комунікативних елементів між публічною владою та суспільством;

- зміна загальних підходів, що являють собою загальні способи вирішення проблем державного та планетарного рівнів в умовах глобалізаційних впливів [2].

В Україні закладено конституційні засади місцевого самоврядування, ратифіковано Європейську хартію місцевого самоврядування, прийнято низку базових нормативноправових актів, які створюють правові та фрінансові основи його діяльності. Проте розвиток місцевого самоврядування фрактично зупинився на рівні територіальних громад міст обласного значення. Існуюча в Україні система та стан місцевого самоврядування не задовольняє потребам суспільства. Істотних кроків з реформування адміністративнотериторіального устрою та органів публічної адміністрації в Україні не здійснено. Існуючий адміністративно-територіальний устрій держави має принципові недоліки, які унеможливлюють децентралізацію та ефективне фрункціонування місцевого самоврядування в інтересах громадян.

Сутнісними ознаками кризи державного управління можна визначити такі:

а) загострення економічних і соціальних конорліктів, що набувають яскраво вираженого політичного характеру;

б) неспроможність державної влади керувати конфрліктами, що розростаються у суспільстві, і регулювати соціально-економічні процеси та відносини традиційними методами;

в) розбалансованість структурно-фрункціональної системи управління й політичних інститутів влади, розрив конструктивних взаємозв'язків із зовнішнім середовищем, крах легітимності державної влади, напружений стан суспільства, що може призвести до політичної катастрофри [6, с. 79].

В Україні макроекономічна система олігархічного типу є об'єктивним явищем. До іï появи в умовах капіталістичного способу виробництва призвели закономірна концентрація і монополізація капіталу. Олігархічна власність властива усім галузям економіки України. Негативні наслідки її функціонування очевидні. Проте олігархічна власність у промисловості сприяла формуванню відносно раціональної галузевої структури економіки південно-східних регіонів. В країні існує малий i середній бізнес, але він майже повністю витіснено олігархічною власністю з промис- ловості і діє переважно у сільському господарстві та сорері послуг. Між представниками олігархічного, середнього та малого бізнесу країни існують протиріччя, але вони не антагоністичні. Розвиток середнього та малого бізнесу здатний обмежити права власності олігархічного бізнесу і на певному етапі сприяти соціально-економічному розвитку країни та її регіонів. Однак такий сценарій є досить сумнівним, оскільки формування олігархічної системи $є$ закономірним процесом. Тем не менш, це певною мірою сприяло розвитку політичних інтересів регіонів, особливо там, де промисловість слабо розвинута і які історично прагнуть до західних країн. До панування в суспільстві через економічні і політичні відносини прагнуть будь які олігархи [11].

Спираючись на досвід зарубіжних країн, країн пострадянського простору, можна виокремити такий метод боротьби $з$ кризою державного управління як розробка антикризової програми оперативного реагування, впровадження в життя оптимальних процедур пошуку та узгодженого прийняття управлінських рішень на всіх рівнях, передбачення у цих процедурах реальних можливостей корегування помилок. Завдяки вдалим управлінським рішенням в кризовий період і знанням антикризового менеджменту можна будувати дієву антикризову програму.

Висновки та перспективи подальших розвідок. Головною метою державного управління має бути процес вирішення наявних конфрліктів такої форми, яка б забезпечувала мінімум політичних, економічних та соціально-етичних втрат, які при цьому неминучі. Економічною підставою політичної кризи в Україні та її регіонах є олігархічна власність, представники якої контролюють систему державного управління, місцевого самоврядування і політичний устрій країни. Для їі вирішення необхідно створення принципово нової структури власності як економічного базису успішного соціально-економічного розвитку та розробка антикризової програми оперативного реагування на перспективу.

Отже, принципами еорективного антикризового державного управління мають бути: науковий аналіз та прогнозування тенденцій; методологія розробки ризикованих рішень; якість антикризової програми; стратегія в управлінні; мистецтво антикризового управління; профресіоналізм антикризового управління; оперативність, гнучкість управління, фрактор часу; моніторинг кризових ситуацій та людський фрактор: персонал, цінності, мотивація. 


\section{СПИСОК ВИКОРИСТАНИХ ДЖЕРЕЛ:}

1. GDP (current US dollars). World Bank. URL: http://data.worldbank.org/indicator/NY.GDP.MKTP.CD?page $=4$

2. Геец В. От квазирынка к рынку и инвестиционному росту. «Зеркало недели. Украина», № 30, 21 августа 2015. URL: http://gazeta.zn.ua/macrolevel/velikaya-depressiya-ukraina.html

3. Сытник Е.А. Диспропорции и кризи. Бизнес Салон. 2008.

4. Кожинов В. Единожды солгав. Завтра. 2000. № 40(357).

5. Україна-2015: національна стратегія розвитку. Громадсько-політичне об'єднання «Український форум». Київ, 2015. 78 с.

6. Орехов В.И. Антикризисное управление : учеб. пособие / В.И. Орехов, К.В. Балдин, Н.П. Гапоненко. Москва : ИНФРА-М, 2008. С. 139-167.

7. Lakey G. Stratrgy of a Living Revalition. Paries, 1982. P. 7, 20.

8. Сабо И. Основы теории права. пер. с англ. Москва : Прогресс, 1974. С. 138.

9. Технология политической власти: Зарубежный опыт. Кн. Дайджест. В.Н. Иванов, В.И. Патрушев, И.В. Молодых. Киев : Вища шк., 1994. С. 89.

10. Портер М. Конкуренция. М. Портер: пер. с англ. Москва : Вильямс, 2000.

11. Концепція розвитку наукової сфери України (проект). Економіст. 2006. № 10. С. 19-21.

\section{REFERENCES:}

1. GDP (current US dollars). World Bank. Available at: http://data.worldbank.org/indicator/NY.GDP.MKTP. $\mathrm{CD}$ ?page $=4$

2. Heets V. (2015). Ot kvazyrunka k rыnku y ynvestytsyonnomu rostu. «Zerkalo nedely. Ukrayna», no. 30, 21 avhusta 2015. Available at: http://gazeta.zn.ua/macrolevel/velikaya-depressiya-ukraina.html

3. Sytnyk E.A. (2008). Dysproportsyy y kryzy. Byznes Salon.

4. Kozhynov V. (2000). Edynozhdy solhav. Zavtra, no. 40(357).

5. Ukraina-2015: natsionalna stratehiia rozvytku. Hromadsko-politychne obiednannia "Ukrainskyi forum". Kyiv, 2015. 78 p. (in Ukrainian)

6. Orekhov V.Y. (2008). Antykryzysnoe upravlenye: ucheb. posobye / V.Y. Orekhov, K.V. Baldyn, N.P. Haponenko. Moscow: YNFRA-M, pp. 139-167.

7. Lakey G. (1982). Stratrgy of a Living Revalition. Paries, pp. 7, 20.

8. Sabo Y. (1974). Osnovu teoryy prava. / per. s anhl. Moscow: Prohress, p. 138.

9. Tekhnolohyia polytycheskoi vlasty: Zarubezhnui oput (1994). Kn. Daidzhest. V.N. Yvanov, V.Y. Patrushev, Y.V. Molodukh. Kyiv: Vyshcha shk., p. 89.

10. Porter M. (2000). Konkurentsyia. M. Porter: per. s anhl. Moscow: Vyliams.

11. Kontseptsiia rozvytku naukovoi sfery Ukrainy (proekt) (2006). Ekonomist, no. 10, pp. 19-21. (in Ukrainian) 